\title{
Konposatu disruptore endokrinoen azterketa kimika analitikoaren ikuspuntutik
}

\author{
(Evaluation of endocrine disrupting compounds \\ from an analytical chemistry point of view)
}

Oihana Ros*, Asier Vallejo, Maitane Olivares, Ailette Prieto, Nestor Etxebarria

Kimika Analitikoa Saila, Zientzia eta Teknologia Fakultatea (UPV/EHU)

*oihana.ros@ehu.eus

DOI: $10.1387 /$ ekaia.17897

Laburpena: Ingurumeneko uretan kutsatzaile organiko desberdinak aurkitzen dira, nahiz eta kontzentrazio baxuetan izan (ng/L mailan). Araztegien irteera korronteak izan ohi dira konposatu horien iturririk nagusietako bat, araztegiek erabiltzen dituzten mekanismoak ez baitira gai kutsatzaileen arazketa osoa burutzeko. Horien artean, konposatu disruptore endokrino (EDC) izenez ezagutzen diren konposatuak aurki daitezke, eta horiek ingurumenean bizi diren espezieetan aldaketa endokrinoak sor ditzakete, nahiz eta EDCak kontzentrazio baxuetan egon. Kalte horien artean, malformazioak, populazioen aldaketak edo intersexualitatea dira nabarmenenak. Hau guztia ikusirik, kimika analitikoaren ikuspuntutik oso garrantzitsua da metodo analitiko sentikorrak garatzea konposatuak ur- eta biota-laginetatik erauzi eta garbitzeko, bai eta konposatuek biotaren atal desberdinetan metatzeko duten joera aztertzeko ere.

Hitz gakoak: konposatu disruptore endokrinoak, erauzketa-metodoak, biokontzentrazioa, ur-laginak, biota.

\begin{abstract}
There are several organic contaminants present in the aquatic environment, even they are find at very low concentrations (ng/L level). The effluents of the wastewater treatment plants (WWTP) can be one of the main sources into the environment, since the mechanism used by the WWTP are not fully efective for the complete removal of the contaminants. Among them, some of them are classified as endocrine disrupting compounds (EDCs) and they can provoke endocrine alterations in the species habiting in the water even they are found at low concentrations. Malformations, a decrease on the polulation or intersexuality are the most significant damages. Thus, the development of highly sensitive analytical methods for the extraction and clean-up of the water and biota samples is vital from an analytical point of view together with the accumulation capacity of the compounds in the different biota compartments.
\end{abstract}

Keywords: Endocrine disrupting compounds, extraction methods, bioconcentration, water samples, biota. 
Oihana Ros, Asier Vallejo, Maitane Olivares, Ailette Prieto, Nestor Etxebarria

Ezin da ukatu kimika gure eguneroko bizitzaren zati garrantzitsu bat denik. Izan ere, «Chemical Abstract Service» (CAS) zerbitzuaren arabera, 110 milioi konposatu kimiko baino gehiago zerrendatu dira gaur egunera arte [1], eta horietatik 100.000 erabiltzen dira gaur egun [2, 3]. Nahiz eta konposatu ezorganiko batzuk ezinbestekoak izan gizakiaren hainbat eginkizunetarako, gaur egun ezagutzen diren konposatu kimiko gehienak konposatu organikoak dira, guztien \% 90 inguru. Hala ere, konposatu berriak sintetizatzen diren heinean, beste batzuen erabilera debekatu egiten da, gizakiengan zein ingurumenean sortzen dituzten kalteengatik. Aipatzekoa da Europar Batasuneko biztanleriari ingurumeneko arazoei buruz galdetu zitzaienean \% 47k adierazi zuela bere kezka nagusia uraren kutsadura zela [4]. Kezka hori ikusirik, konposatu kimikoen presentzia inguruan gero eta erakunde gehiagok aztertzen dute, eta hainbat araudi indarrean daude ingurumenaren kalitatea ahalik eta hobekien mantentzeko.

\section{LEHENTASUNEZKO KONPOSATUAK ETA EMERGENTEAK}

Uraren kutsadurak sortzen duen kezka ikusita, zenbait arau, legedi eta zuzentarau jarri dira indarrean, ingurumeneko uraren kalitatea bermatzeko helburuarekin. Europa mailan, araudirik garrantzitsuena Uraren Zuzentaraua (Water Frame Directive, WFD) da. Mundu mailan, WFDaren parekoa den beste zuzentaraua, Ameriketako Estatu Batuen Ingurumeneko Agentziak (Environmental Protection Agency, EPA) bermatzen duena da. WFDa 2000. urteaz geroztik indarrean dago Europako herrialde guztietan, eta hainbat berrikusketa izan ditu konposatu berriak, eta horiek ingurumenean egon daitezkeen kontzentrazio maximoak finkatzeko. Helburu nagusia da ingurumeneko ur guztiak (gainazalekoak, lur azpikoak, trantsiziokoak eta kontinentalak) kalitate egokian mantentzea. Horrenbestez, urek zuzentarauak ezarritako ingurumeneko kalitate-mugak (Environmetal Quality Standards, EQS) betetzen dituztenean, kalitate egokia lortu dutela baiezta daiteke. EQS balioak 2008. urteko berrikusketan gehitu ziren [5], uretarako, biotarako eta sedimentuetarako kontzentrazio-mailak finkatuz.

Aipatutako bi zuzentarau horiek konposatu kimikoek ingurumenean duten presentzia arautzea dute helburu. Konposatuen kontzentrazio-maila EQS gainetik dagoenean eta posiblea den kasuetan, konposatu horien isuria eten egin behar da. Ezinezkoa balitz, gutxienez inolako eraginik sortzen ez duten mailetara jaitsi behar dira (EQS balioen azpitik). Araututako konposatu horiek lehentasunezko konposatuak dira, ingurumenean duten kalte ezagunagatik. WFDk, 2000. urtean, 33 substantzia sailkatu zituen multzo horretan (2000/60/EC eranskinean) [6], eta azkeneko berrikusketaren ondoren (2013. urtean, 2013/39/EC), beste 12 konposatu gehitu zituen zerrenda horretara. Horrela, gaur egun, 45 konposatu sailkatzen dira lehentasunezko konposatu modura [7]. EPAko zuzentarauak, aldiz, uraren programa erre- 
gulatzailearen (Water Regulatory Program) barnean, 126 konposatu sailkatu ditu lehentasunezko konposatu bezala [8]. Multzo horretan, honako hauek aurki daitezke, beste familia batzuen artean: zenbait metal, pestizida, ftalato ester (Phthalate Esters, PE), hidrokarburo polizikliko aromatiko (Polycyclic Aromatic Hydrocarbons, PAH), alkilfenol (Alkyl Phenols, AP) eta dioxina.

Lehentasunezko konposatuez gain, badira aipaturiko zuzentarauetan lehentasunezko moduan sailkatzen ez diren beste hainbat konposatu; konposatu emergenteak, alegia. Konposatu horiek gizakiarengan zein ingurumenean kaltea eragin dezaketelako susmoa dago. Gainera, konposatu asko eta asko ingurumenean maiz aurkitzen diren konposatuak dira. Informazio nahikorik ez dago gaur egun lehentasunezko kutsatzaileen artean sailkatzeko, baina monitorizazio-programetan sartzea gomendatzen da hurrengo azterketa batean lehentasunezko multzoan sartu behar diren ala ez erabakitzeko. Talde horren barnean, zaintza pertsonaleko produktuak eta produktu farmazeutikoak (hormonak, adibidez) daude WFD [9] eta EPA [10] zuzentarauetan.

Konposatu emergenteen multzoan egon beharreko konposatuak finkatzeko, Europako eta Ipar Ameriketako zientzialariek eta erakundeek lanean dihardute 2005. urteaz geroztik NORMAN izeneko proiektuan. NORMAN proiektuan ikertzen duten lan-taldeen helburua, konposatu emergenteak neurtzeko metodoak bateratzea eta horien monitorizazioari buruzko arauak ezartzea da. WFDko eta EPAko zuzentarauek kontuan hartu ez dituzten hainbat konposatu, kutsatzaile emergenteen taldean sartzea proposatu dute NORMANeko kideek. Horietatik aipagarrienak musketa fragantziak, surfaktanteak, produktu farmazeutikoak, hormonak, pestizida polarrak eta biozidak dira. Horiek guztiek, gizakien eta animalien sistema endokrinoan eragiten dituzten aldaketak direla-eta [11], konposatu disruptore endokrino (Endocrine Disrupting Compound, EDC) izenez ezagutzen dira.

\subsection{Konposatu disruptore endokrinoak}

EDCak gorputzaren sistema endokrinoan aldaketak sortzen dituzten substantzia exogenoak edo horien nahasteak dira. Konposatu horiek organismo osasuntsuetan edo organismo horien ondorengoetan kalteak sor ditzakete [12]. Disrupzio endokrinoa elikaduran edo ingurumenean dauden kutsatzaileek sor dezakete.

EDCek gorputzean kalteak eragiteko bi mekanismo nagusi dituzte. Alde batetik, gorputzean era naturalean dauden hormonen jokaera imita dezakete eta, beste aldetik, hormonen produkzioan, metabolismoan edo kanporatzean parte har dezakete [12]. 1 irudian ikus daitekeen moduan, egoera normal batean, hormona hormona-hartzaileari lotzen zaio. Haatik, EDC bat jatorrizko hormonarekin lehian dagoenean, EDCa hormona-hartzaileari lot dakioke hormonaren erantzun normala aldatuz. 
Oihana Ros, Asier Vallejo, Maitane Olivares, Ailette Prieto,

Nestor Etxebarria

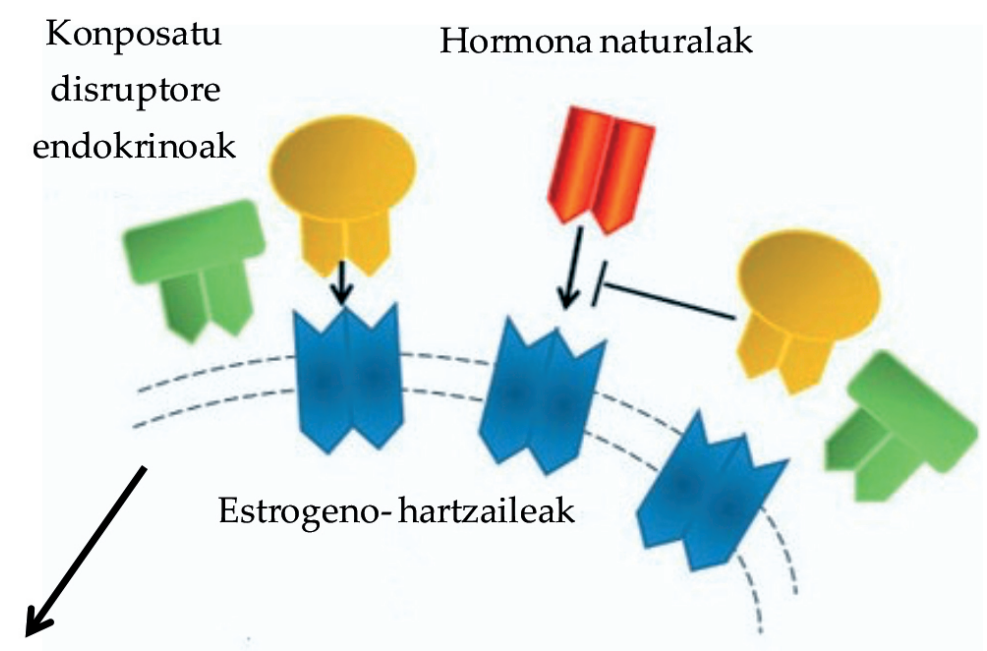

\section{Erantzun zelularra}

1. irudia. Disruptore endokrinoak eta hormona naturalak estrogeno-hartzailearekin lotzen diren adibidea.

Erantzun desberdin horien ondorioz, hainbat izan dira uretan bizi diren espezieetan aurkitutako arazoak: besteak beste, malformazioak [13], ugalketa-arazoak [14], espezieen tamainaren aldaketa [15] edo intersexualitatea $[15,16]$. Arazo horiek, bai ingurumenean jasotako arrainetan, bai laborategiko arrainetan aurkitu izan dira, arrainek pairatu duten esposizio-maila oso baxua izanda ere.

Intersexualitatea edo «ovotestis»a, garapen-maila desberdinean egon daitezkeen obozitoak barrabilen ehunaren barruan daudenean gertatzen den fenomenoa da [16, 17]. Ohikoa ez den egoera horren ondorioz, arrainetan ugalketa arazoak ikusi dira, eta, kasurik larrienetan, populazio osoa desagertzeko zorian egon da [18]. Ezaguna da intersexualitatea sortzen duen faktorerik garrantzitsuenetako bat EDCekiko esposizioa dela [15-17], bai larba garaian bai eta heldutasun sexuala lortu dutenean ere [19].

EDC gehienek jatorri sintetikoa dute. Edonola ere, badira jatorri naturala duten EDCak ere, hormona naturalak eta sojatik eratorritako fitoestrogenoak, adibidez [20, 21]. Konposatu sintetikoen artean, PEak, bisfenol-A (Bisphenol-A, BPA), musketa fragantziak, APak, hormona sintetikoak eta pestizidak aipa daitezke, besteak beste. Konposatu horietatik gehienak lehenago aipatutako zuzentarauetan aipatzen dira espezifikoki sortzen dituzten kalteengatik. Hala ere, dietilestilbestrola (Diethylestilbestrol, DES) eta musketa fragantzia konposatuak, nahiz eta EDC moduan sailkatu diren, NORMAN lan-taldean baino ez dira aipatzen. 


\section{KONPOSATU KIMIKOAK INGURUMENEAN}

Aipatu berri den moduan, milioika dira gaur egun erabiltzen diren konposatu kimikoak, eta ondorioz, milioika dira ingurumenean amaitzen duten konposatuak ere. Konposatu organikoen propietate fisiko-kimikoek, beste faktore batzuen artean, uretan eta biotan duten disolbagarritasun-maila finkatzen dute. Oro har, oktanol-ur banaketa-koefizientea ${ }^{1}$ (octanol/water Partition Coefficient, $\mathrm{K}_{\text {ow }}$ ) baxuena duten konposatu kimikoak uretan disolbagarriagoak dira. Beraz, $\mathrm{K}_{\text {ow }}$ balioa handituz doan heinean, biotan metatzeko aukera handitu egiten da.

\subsection{Konposatu kimikoak ur-ingurumenean}

Ura gizakion bizitzarako ezinbestekoa den arren, esfortzu txikia egiten da osasuntsu mantentzeko. Urteetan zehar gizakiaren jardueren ondorioz (industria, nekazaritza, abeltzaintza, eta abar) sortutako hondakinak ingurumeneko uretara isurtzen ziren. Produktu kimikoen erabilera handituz joan ahala, gero eta produktu gehiago isuri dira ingurumeneko uretara. Arazo horri aurre egin nahian, XIX. mendearen amaieran araztegiak sortu ziren. Araztegien helburua ur industrialak edota etxeko urak jasotzea da, eta, tratamendu fisikoak, kimikoak edo biologikoak aplikatu ostean, teorian, ingurumenerako kaltegarriak ez diren baldintzetan lortutako «ur garbia» ingurumenera bueltatzea da. Araztegi gehienek bi tratamendu burutzen dituzte, nahiz eta hirugarren tratamendu bat ere izan daitekeen.

Urak, araztegira heltzen direnean, aurretratamendu urrats batzuk jasaten dituzte, lehen objektu handiak (enborrak edo plastikozko poltsak), objektu txikiak, uretan dauden area-aleak edo antzeko tamaina duten partikulak eta gainazalean dauden koipeak kentzeko. Aurretratamenduaren ostean, urek lehen mailako tratamendua jasaten dute ahalik eta materia organiko gehien dekantatzeko. Urari tratamendu kimiko desberdinak egiten zaizkio, koagulazio/malutapen-prozesuak erabiliz. Tratamendu horien ondorioz, solidoak dekantatzen dira bi azpi-produktu sortuz; ur-laginak eta solidoak edo lohiak. Ondorengo urratsetan, urek eta lohiek tratamendu desberdinak jasango dituzte. Ondoren, urek bigarren mailako tratamendua jasaten dute. Han, mikroorganismo desberdinak erabiliz, uretan disolbatuta dagoen materia organikoaren deskonposizioa eragiten da, non, oxigenoaren laguntzaz, mikroorganismoek materia organikoa deskonposatzen duten, eta, bestalde, ura eta partikula solidoak bereizten diren. Kasu askotan, araztegien arazketa prozesua urrats horretan amaitzen da. Tratamendu tertziarioaren helburua da ultramore izpiak edo klorazioa erabiliz metal astunen eta hainbat

\footnotetext{
${ }^{1}$ Oktanol-ur banaketa-koefizientea: $\mathrm{K}_{\mathrm{ow}}=\mathrm{C}_{\mathrm{oktanol}} / \mathrm{C}_{\mathrm{ura}}$.
} 
Oihana Ros, Asier Vallejo, Maitane Olivares, Ailette Prieto, Nestor Etxebarria

konposatu kimikoren degradazioa egitea. Gero eta gehiago dira tratamendu hori burutzen duten araztegiak.

Aipatu berri den bezala, araztegietan hainbat prozesu fisiko-kimiko egiten dira urak ingurumenera bueltatu aurretik. Halaz guztiz ere, hainbat lanetan aipatu da araztegiak ez direla gai konposatu kimiko guztiak ezabatzeko [22-25]. Araztegiak sortu ziren garaian, gaur egun ezagutzen diren hainbat konposatu organiko ez ziren ezagutzen, eta, ondorioz, araztegietan egiten diren tratamenduak ez dira gai konposatu organiko guztiak arazteko, ez baitago tratamendu espezifikorik oraindik ere indarrean. Horrez gain, aipatu beharra dago araztegien irteerako urek konposatu organikoen aurrekontzentrazio gisa joka dezaketela.

Estuarioetako, erreketako edo lakuetako uretan aurki daitezkeen konposatu organikoen kontzentrazioak araztegien irteeren ondoan aurki daitezkeenak baino baxuagoak dira diluzio efektua dela-eta $[22,24,26]$. Oro har, estuarioko eta errekako uretan konposatu gehienak ng/L-ko mailan daude, zenbait AP [23] eta PEak [26] izan ezik, ng/mL mailan aurkitzen baitira. Hala ere, aipatutako kontzentrazio horiek araztegietako irteeretan neurtutakoak baino baxuagoak dira eta kasu askotan $\mu \mathrm{g} / \mathrm{L}$-ko mailakoak dira.

\subsection{Konposatu kimikoak biota-laginetan}

Ingurumeneko uretan dauden konposatu kimikoen kontzentrazioa ezagutzea ezinbestekoa da ingurumenean bizi diren espezie urtarren osasuna ezagutzeko. Aipatu berri den moduan, konposatu organiko gehienak oso kontzentrazio baxuetan egoten dira ingurumenean, ng/L-ko mailan gehienetan. Kontzentrazioak toxikotasun-mailakoak baino baxuagoak diren bitartean, balio horiek ez lukete arriskurik ekarri beharko. Alabaina, etengabeko esposizioak arazoak ekar ditzake uretan bizi diren espezieetan $[16,27,28]$. Arrainek konposatu toxikoak barneratzeko 3 bide nagusi dituzte: elikadura, larruazala eta arnasketa. Arnasketaren bidez barneratu diren konposatuak zakatzetatik sartzen dira, eta odolaren bidez garraiatzen dira gorputz osotik zehar, organoetan metatzeko aukera badelarik. Arnasketa bidearen bitartez konposatuak metatzeko joera sakonago aztertuko da, kaltetutako organoen funtzioa azalduz. 2 irudian, EDCen metaketan garrantzia duten arrainen zenbait atal ikus daitezke. 


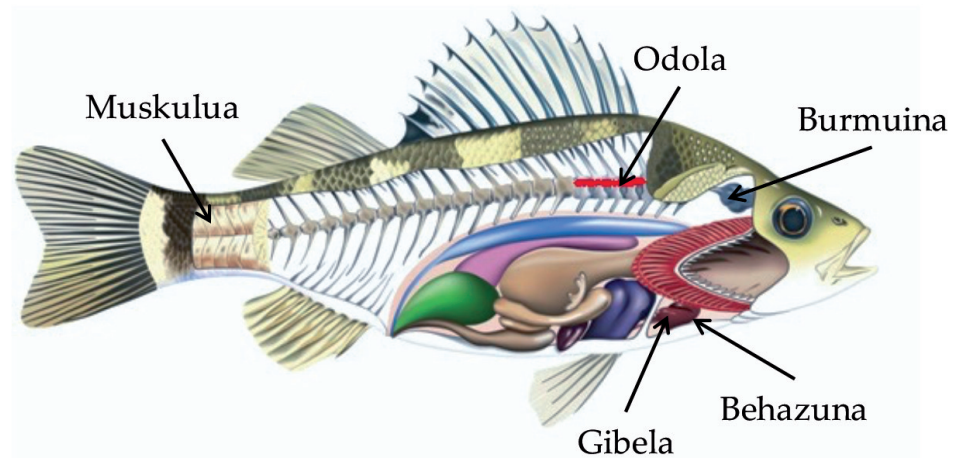

2. irudia. EDCen metaketa arrainetan aztertzeko garrantzitsuak diren zenbait atal.

\subsubsection{Odola}

Arrainek odol-sistema itxia dute. Bihotzak ponpatzen duen odola oxigenatzeko zakatzetara joaten da lehenbizi, eta ondoren gorputz osotik zehar garraiatzen da. Zakatzen bidez barneratutako konposatu organikoek odola erabiltzen dute garraiobidetzat. Konposatu organikoek ez dute odolean metatzeko joera handirik erakusten eta ng/mL-ko maila oso baxuetan antzeman dira [29, 30]; zenbait kasutan, uretan dauden kontzentrazio-maila berdinean.

\subsubsection{Gibela}

Konposatu kimikoak odolaren bidez heltzen dira gibelera gorputzetik kanporatuak izan aurretik. Konposatu arrotzak egonkorragoak eta polarragoak diren konposatuetara metabolizatzen ditu gibelak, behazunaren bidezko kanporatzea laguntzeko. Konposatuek bi erreakzio-mota jasan ditzakete gibelean. Lehenik eta behin, 1. fasea (Phase I) deritzon prozesuaren bidez, konposatu organiko batzuk (ez-polarrenak) eraldatu egiten dira polarragoak diren metabolitoetan [31]. Oro har, metabolito berri horiek alkohol $(-\mathrm{OH})$ edo azido $(-\mathrm{COOH})$ talde bat daukate. Bigarren erreakzioari 2. fasea (Phase II) deritzo. Han, metabolito berri horien $-\mathrm{OH}$ edo $-\mathrm{COOH}$ taldeei glukuronido [32-34], glukosido [35] edo sulfato [32] talde bat lotzen zaie, konposatu polarragoak lortuz; hartara, behazunaren bidez kanporatzeko errazagoak diren konposatuak bilakatuz. Konposatu polarragoak (eraldatu gabe $-\mathrm{OH}$ edo $-\mathrm{COOH}$ taldea daukatenek) ez dute 1. fasea pairatzen, eta zuzenean 2. fasean transformatzen dira.

Legler eta haren lankideen arabera, adibidez, 17- $\beta$ estradiolaren (17- $\beta$ estradiol, E2) hormonaren \% 90 glukuronido moduan askatzen 
Oihana Ros, Asier Vallejo, Maitane Olivares, Ailette Prieto, Nestor Etxebarria

da [36]. Konposatu glukuronidoak ez dira estrogenikoki aktiboak [37, 38], baina araztegietan dauden bakterioek konposatu glukuronidoak hidroliza ditzakete jatorrizko konposatu bihurtuz.

Odolarekin gertatzen ez den bezala, konposatu kimikoek gibelean metatzeko joera dute [20,39]. Aipatu behar da, pestizida organofosfatatuen kasuan adibidez, sortzen diren metabolitoak jatorrizko pestizidak baino toxikoagoak direla [40]; beraz, oso garrantzitsua da gibelean sor ditzaketen ondorioak aurreikusteko metatzen diren konposatuak aztertzea.

\subsubsection{Behazuna}

Gibelean metabolizatutako konposatuak behazunera gorputzetik kanporatuak izateko helburuarekin heltzen dira [28, 33]. Hori dela eta, behazuna da konposatu organikoak maila altuenean dauden ehuna [34, 41]: zenbait kasutan ppm-ko mailara hel daitezke. Adibide moduan, aipagarria da Ingalaterrako araztegi bateko irteeran arrantzatutako arrain baten behazunean neurtutako nonil-fenol (nonyl-phenol, NP) maila $12 \mathrm{mg} / \mathrm{L}$ baino handiagoa zela [34]. Esan beharra dago elikagaiak digeritzeko erabiltzen den bakoitzean behazun-xixkua hustu egiten dela. Hori dela eta, behazunean aurki daitezkeen kutsatzaileak esposizio laburrekoak dira, Martinez-Gomez eta haren lankideen arabera ordu gutxi eta zenbait egun bitartekoak [28]. Arrazoi horregatik bai eta behazunak duen metaketa ahalmenagatik ere, ikertzaile askok behazuna proposatzen dute biomonitorizazioetan neurtu beharreko ehuntzat $[28,32]$.

\subsubsection{Muskulua}

Azaletik barneratzen diren konposatuek epe luzean muskuluan metatzeko joera dute. Oro har, aztergai diren konposatu organikoak ng/mL maila baxuetan metatzen dira muskuluan [39, 42]. Egia da kontzentrazio horiek ingurumeneko uretan aurki daitezkeenak baino handiagoak direla. Horregatik, oso garrantzitsua da arrainaren muskuluan metatzen diren konposatuen kontzentrazioak ezagutzea, ez arrainean izan dezakeen toxikotasunagatik bakarrik, baita muskulua jatean gizakiengan sor daitezkeen arazoengatik ere.

\subsubsection{Burmuina}

Arrainen burmuinak lipidoen metabolismoaren, sexu-hormonen jariatzearen, hazkuntzaren, osmorregulazioaren eta garapen sexualaren portaera kontrolatzen du, besteak beste. Heldu gabeko arrainetan, uste da ezinbesteko garrantzia dutela esteroideek burmuinean dagoen gonada pituitarioaren garapenean . Azken horrek, arrain heldu baten ugalketa-zikloa kontrolatuko du [43]. Beraz, burmuinean dauden EDCen kontzentrazioa jakitea 
ezinbestekoa da arrainaren garapenean arazorik izan daitekeen ala ez aurresateko.

\section{INGURUMENEAN DAUDEN KONPOSATU KIMIKOEN ANALISIA}

Kimika analitikoaren erronka nagusietako bat, nagusia ez bada, laginen aurretratamendua ahalik eta era egokienean egitea da. Ahalegin handia egin behar da laginaren aurretratamendu egokia gauzatzeko, baina pausu horren egokitasun ezak analisi osoaren porrota ekar dezake. Beraz, kimika analitikoaren helburua, aurretratamenduaren ikuspuntutik, doiak, zehatzak, sentikorrak, sendoak eta selektiboak diren metodoen garapena da. Horretaz gain, oso garrantzitsua da ingurumenarekiko errespetagarriak diren teknikak garatzea.

\subsection{Lagin likidoak}

Lagin likidoetako konposatu organikoen analisirako erabili diren teknikarik ohikoenak likido-likido erauzketa eta fase solidoko erauzketa (Solid Phase Extraction, SPE) izan dira. [24, 44, 45]. Bi teknika horiek oso eraginkorrak dira konposatu organikoak erauzteko, baina denbora oso luzeak behar izaten dira, eta, gainera, ez dira ingurumenarekiko guztiz errespetagarriak, zeren eta disolbatzaile organikoen bolumen handiak behar izaten baitira. Azken urteotan, disolbatzaile organiko gutxiago, edo disolbatzaile organikorik behar ez duten mikroerauzketa teknikak garatu dira, «sorptive» (adsortzio edo absortzio moduan) erauzketa-metodoetan oinarrituz [46]. Teknika horien aitzindaria fase solidoko mikroerauzketa (Solid Phase Microextraction, SPME) da. Teknika hori Pawliszyn eta haren lankideek erabili zuten lehenbiziz 1990. urtean [47], eta ordutik hona oso teknika erabilia izan da konposatu organikoen azterketarako ur-laginetan [46, 48], arrainen behazunean [49], giza plasman [50] eta giza gernuan [48]. Teknika guztiek bezala, SPMEk desabantaila garrantzitsu bat du: SPMEaren bidez lortzen diren detekzio-mugak ez dira behar bezain baxuak ingurumeneko uren analisia zuzenean burutzeko [25]. SPMEaren printzipio bera duten teknika gehiago garatu dira, ingurumeneko laginen analisirako baliagarriak. Teknika horietako batzuk hagatxo birakarien bidezko erauzketa (Stir Bar Sorptive Extraction, SBSE) edo polimero desberdinen bidezko mikroerauzketa dira. Lehenbiziko teknikan polidimetilsiloxano polimeroaz (Polydimethylsiloxane, PDMS) estalitako hagatxoak erabiltzen dira. PDMSa analito ez-polarrak erauzteko polimero egokiena da [45]. Analito polarrak erauzteko, ordea, polimero desberdinak erabil daitezke, azken urteetan emaitza oparoak eskaini dituen polimeroetako bat polietersulfona (Polyethersulfone, PES) izan da (3. irudia). 
Oihana Ros, Asier Vallejo, Maitane Olivares, Ailette Prieto, Nestor Etxebarria

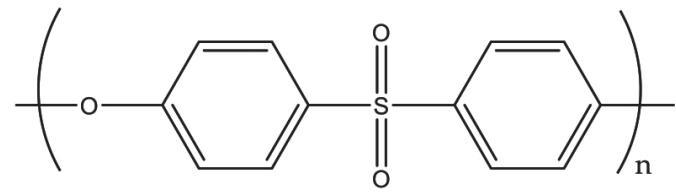

3. irudia. PES polimeroan egitura kimikoa.

PES polimeroa konposatu polarrak zein ez-polarrak erauzteko erabili izan da. 0,07-6,88 bitarteko $\log \mathrm{K}_{\mathrm{ow}}$ balioa duten analitoetarako egokia dela frogatu da [45]. Musketa fragantziak, APak, hormonak, konposatu farmazeutikoak, PEak, pestizidak, konposatu perfluorinatuak ur-laginetatik erauztea lortu dute hainbat ikertzailek $[25,45,51]$. PES polimeroak, polartasun desberdineko konposatuak erauzteaz gain, kostu baxua $(\sim 0,05 € /$ analisi) du komertzialki saltzen diren hagatxoekin alderatuz. Kostu baxu horri esker, ez dago hagatxoak berrerabili beharrik.

\subsection{Lagin solidoak}

Lagin solidoen erauzketari dagokionez, solido-likidoan oinarritzen diren teknikak erabiltzen dira. Urteetan zehar, Soxhlet teknika da gehien erabili izan dena [52]. Lagin likidoen erauzketan gertatzen den moduan, teknika klasikoek disolbatzaile organikoen bolumen handiak $(100-250 \mathrm{~mL})$ behar izaten dituzte, eta nahiko denbora luzeak erauzketa-urratsa burutzeko. Teknika analitiko berrien garapenarekin erauzketa-metodo berriak garatu dira. Horien artean aipagarrienak dira mikrouhinen bidezko erauzketa (Microwave Assisted Extraction, MAE), ultrasoinuen bidezko erauzketa (Ultrasound Extraction, USE) eta presiopeko likido erauzketa (Pressurised Liquid Extraction, PLE). PLEaren eta MAEaren kasuan (sistema itxian lanean ari bagara), disolbatzailea presiopean dago eta, presioa igoz disolbatzaile organikoaren irakite-tenperatura ere igotzen denez, tenperatura altuagoetan lan egin daiteke erauzketa faboratuz eta ondorioz denbora laburtuz [53, 54]. Erauzketa-teknika horiekin, erauzketan erabili behar den disolbatzaile organikoaren bolumena ere asko murriztu da (10-25 mL).

Disolbatzaile organiko gutxi erabiltzen duen beste teknika bat USE da. USE erauzketan, lagina disolbatzaile organiko batekin edo disolbatzaile-nahasketa batekin jartzen da kontaktuan eta ultrasoinu-energiaren bidez erauzten dira konposatuak. USE tekniken artean, ultrasoinu fokatu bidezko solido-likido erauzketa (Focused Ultrasound Solid Liquid Extraction, FUSLE) garrantzia hartzen hasi da azken urteotan biota laginetatik APak [55], hormonak [55], PAHak [56, 57] eta konposatu perfluorinatuak [58] aztertzeko, ohiko ultrasoinu-bainuak baino errepikakorragoa baita. FUSLEn, disolbatzaile organikoan murgilduta dagoen titaniozko edo beirazko punta baten bidez egiten da sonikazioa, eta lortzen den indarra ul- 
trasoinu-bainuan lortzen dena baino 100 bider handiagoa da [59]. Energiafokatze horren ondorioz erauzketa-denborak segundo eta minutu gutxi batzuetara labur daitezke [60].

Aipatu diren teknika guztiak, bai lagin likidoetatik analitoak erauztekoak, bai lagin solidoetatik erauztekoak, ez dira oso selektiboak eta intereseko analitoez gain hainbat interferentzia ere erauzten dituzte [60, 61]. Kasu gehienetan interferentziak ezabatzeko garbiketa urrats bat egin behar izaten da analisiaren aurretik.

\subsection{Garbiketa-teknikak}

Aipatu berri den moduan, kasu askotan garbiketa urrats bat egin behar izaten da laginean dauden interferentziak ezabatu edo minimizatzeko. Interferentziak interesezko konposatuekin nahas daitezke, eta lortzen diren emaitzek ez dute zertan benetakoak izan.

Lagin solidoen eta likidoen garbiketa-urratsa egiteko, garbiketa-teknika berdinak erabil daitezke. Hala ere, aztertu nahi den matrizearen arabera, erauzitako interferentziak desberdinak dira, eta horrek finkatzen du aukeratu beharreko garbiketa-teknika.

Garbiketa-teknika klasikoen artean, SPE delakoa da erabiliena [60]. SPE teknikak lagin likidoetatik analitoak erauzteko erabiltzen diren teknikek duten oinarri bera du. Florisil ${ }^{\circledR}$, silizea eta alumina dira ur- [24, 62] eta biota-laginen [63] garbiketarako gehien erabiltzen diren adsorbatzaileak. Garbiketa urratsean erabiltzen diren adsorbatzaileen masak handiak izan ohi dira (150-5.000 mg) eta, ondorioz, kartutxoa egokitzeko, interferentziak ezabatzeko eta analitoak eluitzeko erabili behar den disolbatzaile organikoaren bolumena ere handia da. Gel-permeazio kromatografia ( $\mathrm{Gel}$ Permeation Chromatography, GPC) asko erabili izan den beste garbiketateknika bat da, batez ere biota-laginek duten koipea kentzeko [64]. Zutabe kromatografiko bereziak erabiliz, tamainaren araberako banaketa egiten da, koipeak zutabean atxikita geratzen dira eta intereseko molekulak bakarrik eluitzen dira. GPCan, SPEan bezala, disolbatzaile organikoen bolumen handiak erabili behar izaten dira; hala eta guztiz ere, gaur egun asko erabiltzen dira [65].

Erauzketa-teknikekin gertatzen den moduan, kimika analitikoan egindako aurrerapenei esker, ingurumenarekin egokiagoak diren teknikak garatu dira. Garbiketa-metodo klasikoei irtenbidea emateko, fase solidoko erauzketa dispertsoaren (Dispersive Solid Phase Extraction, dSPEaren) erabilera asko hedatu da azken urteotan $[13,44,60]$. dSPE teknikaren erabilera Anastassiadeek eta haren lankideek [66] proposatu zuten estrainekoz «QuEChERS» (Quick Easy Cheap Effective Rugged Safe, azkarra erraza merkea eraginkorra sendoa segurua) metodoarekin batera. dSPE metodoaren abantaila nagu- 
Oihana Ros, Asier Vallejo, Maitane Olivares, Ailette Prieto,

Nestor Etxebarria

siak dira erabiltzen diren disolbatzaile organikoaren bolumen txikia eta prezio merkea. Ohiko SPE zutabeetan erabiltzen diren adsorbatzaileak erabil daitezke dSPEan. Gehien erabili diren adsorbatzaileak hauexek dira: amina primarioak eta sekundarioak gantz azidoak kentzeko, ENVI-CARBa esterolak eta pigmentuak kentzeko eta oktadezilsilanoa $\left(\mathrm{C}_{18}\right)$ interferentzia ezpolarrak kentzeko $[44,61]$. Zenbait kasutan, ur-arrastoak kentzeko $\mathrm{MgSO}_{4}$ ere gehitzen zaio. dSPE urratsean aukeratutako fasea edo faseen nahasketak $\mathrm{MgSO}_{4}$ eta intereseko analitoak dituen erauzia tutu batean nahasten dira eta irabiagailu baten laguntzaz irabiatzen da nahastea fase solidoa dispertsatzeko. Fasea dekantatu ostean, intereseko analitoak disolbatzailean geratzen dira, eta interferentziak, adsortzio fasean adsorbaturik (4. irudia).

Interferentziekiko afinitate altua duen adsorbatzailea aukeratu behar da eta analitoekiko afinitate handia duen disolbatzailea, aldiz. dSPE metodoa BPA [61], hormonak [61] eta pestizidak [65] biota-laginen garbiketarako erabili dira maiz, baita konposatu organikoak plasmatik [44, 67], gernutik [67] eta elikagaietatik [68] erauzteko ere.

4. irudian, lan honetan erabili diren analisi tekniken laburpena agertzen da.

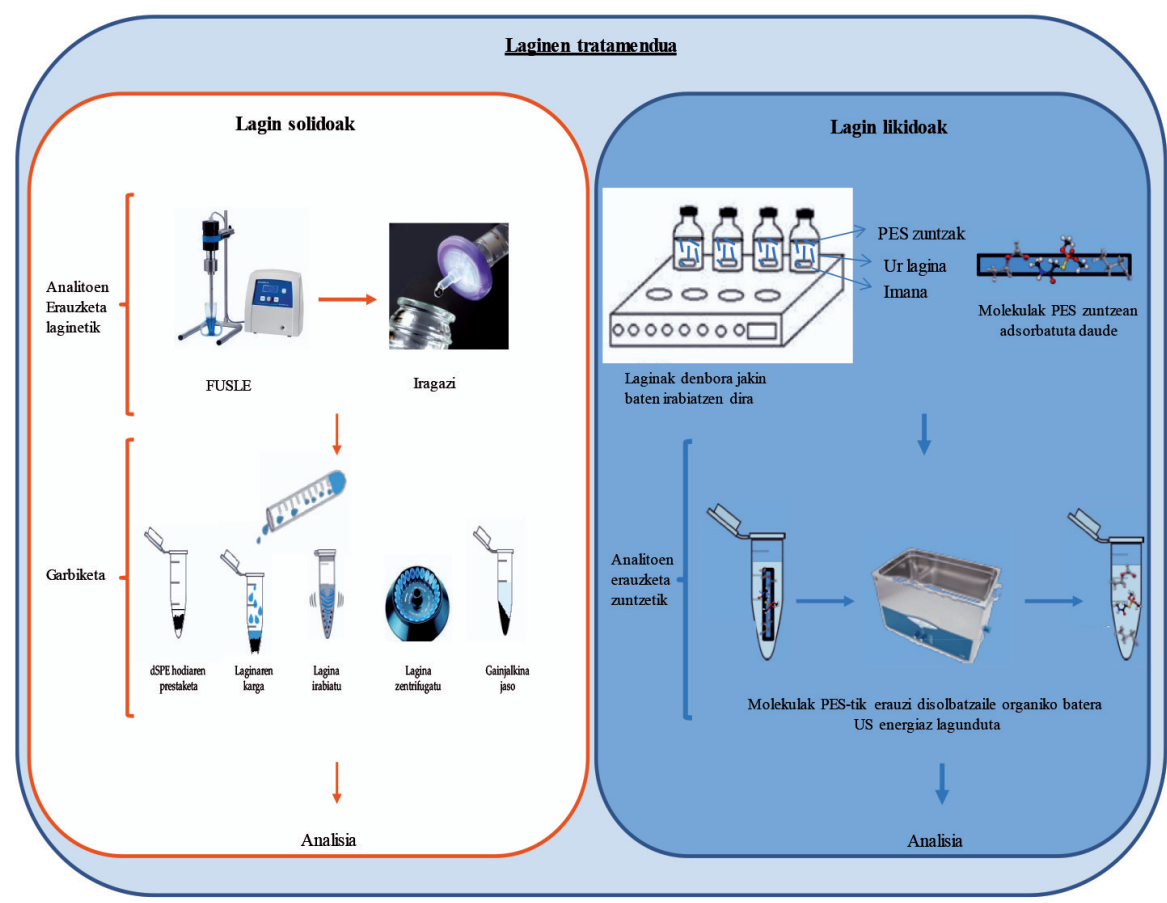

4. irudia. Lan honetan erabilitako teknika analitikoen laburpena. 


\section{KONPOSATU KIMIKOEN METAKETA}

Lan honetan zehar aipatu bezala, konposatu organiko gehienak oso kontzentrazio-maila baxuetan daude ingurumeneko uretan, askotan detekzio-mugaren azpitik. Arrainek, ordea, konposatu horiek metatzeko gaitasuna dute, eta hori dela bide, kontzentrazio-maila altuagoetan aurki daitezke. Beraz, ikertzaile askok arrainak eta muskuiluak erabili dituzte biomonitorizazio-tresnatzat $[69,70]$.

\subsection{EDCen metaketa arrainetan}

Arrainek duten metaketa-gaitasuna neurtzeko biokontzentrazio-faktorea (bioconcentration factor, BCF) erabiltzen da. Faktore horrek modu errazean erlazionatzen ditu konposatu batek ehun jakin batean daukan kontzentrazioa $\left(\mathrm{C}_{\text {analito ehunean }}\right)$ konposatu berak uretan daukan kontzentrazioarekin $\left(\mathrm{C}_{\text {analito uretan }}\right)$ (1. ekuazioa). BCFak kalkulatzeko, konposatuek orekara iritsi behar dute. Laborategietan kontrolpean egiten diren esperimentuetan kutsatzailearen metaketa orekara heldu dela ziurta daitekeen bitartean, zelaiko laginetan ezinezkoa da hori ziurtatzea. Ondorioz, laborategiko baldintzetan eta zelaiko laginetan ikusitako BCF balioak desberdinak izan daitezke.

$$
B C F=\frac{C_{\text {analito ehunean }}}{C_{\text {analito uretan }}} \quad \text { 1. ekuazioa }
$$

BCFez gain, bioakumulazio- edo biometatze-faktoreak (Bioaccumulation Factor, BAF) ere kalkula daitezke. BAFak kalkulatzeko, uretako kontzentrazioa neurtzeaz gain, arrainaren kutsatzaile organikoekiko esposizio osoa hartu behar da kontuan, elikadura barne [71]. Kontrolpeko esperimentuetan janarian eta airean dauden konposatuen kontzentrazioak neur daitezke, baina ingurumeneko azterketan nahiko zaila izaten da; beraz, ikertzaileari gehienek BCF parametroa erabiltzen dute. Konposatu bat maila handian metatu den ala ez aurresaten duen balio finkorik ez dago. Kanadako gobernuak plazaratu zuen gida baten arabera [72], BCF balioa 5.000 baino handiagoa denean konposatu horiek biokontzentratu direla esan daiteke. Lee eta haren lankideen arabera, ordea [73], BCFa 1.000 baino handiagoa denean, esan daiteke konposatuak biokontzentratu direla. Inoue eta haren lankideen arabera [74], aldiz, BCF balioa 2.000-5.000 artean badago, konposatuek metatzeko joera dutela esan daiteke, eta $\mathrm{BCFa} 5.000$ baino handiagoa denean, berriz, metatzeko oso joera handia dutela diote.

BCF teorikoak kalkulatzeko ikertzaile askok $\log \mathrm{k}_{\mathrm{OW}}$ balioak erabili dituzte $[71,75]$. BAF eta BCF faktoreak esperimentalki kalkulatzea ezinezkoa denean, Kanadako gobernuak, kasurako, $\log \mathrm{K}_{\mathrm{ow}} 5$ edo handiagoa 
Oihana Ros, Asier Vallejo, Maitane Olivares, Ailette Prieto, Nestor Etxebarria

duten konposatuek zuzenean metatzeko joera dutela adierazten du. Eredu horren arabera, BCFaren eta $\log \mathrm{K}_{\text {ow }}$ aren arteko erlazioa zuzena dela onartzen da. Zenbait ikertzailek, ordea, erlazio hori parabolikoa dela baieztatu dute [75]. Arlo horretan ere, BCF eta BAF faktoreak teorikoki kalkulatzeko lan asko dago egiteko, parametro bakarrean guztia oinarritzeak ez baitauka zentzurik.

BCF teorikoak kalkulatzeko, badirela zenbait metodo ikusi da. BCF esperimentalak hainbat faktoreren menpekoak dira: arrain-espeziea, sexua, tamaina, elikadura-ohiturak eta ingurumeneko baldintzak, besteak beste $[64,73]$. Beraz, oso zaila izaten da ikerketa-lan batean lortu diren $\mathrm{BCF}$ balioak beste ikerketa lanetakoekin erkatzea. Esperimentalki kalkulatu diren $\mathrm{BCF}$ gehienak muskulu-laginei dagozkie; azken finean, hau baita gizakiok jaten dugun atala. Oro har, BCF faktoreak nahiko baxuak dira muskuluan [20, 27, 52, 73], betiere Lee eta haren lankideek [73] proposatzen duten 1.000 baliotik beherakoak, konposatu eta arrain-espezie desberdinetarako. Kontrako muturrean behazunean kalkulatutako BCFak daude. Horiek ingurumenean jasotako arrain-espezie desberdinetarako 1.000-20.000 izatera iritsi dira $[27,32,76]$. Muskuluan ez bezala, behazunean kalkulatu diren BCFak ikusita, behazuna biomonitorizazio-ehuntzat erabil daitekeela esan daiteke. Gainera, behazunak berrikitan barneratutako konposatuei buruz ematen du informazioa.

\section{ADIBIDE PRAKTIKOAK: EDCEN NEURKETA ZELAIKO LAGINETAN}

Aurretiaz aipatu diren metodo guztiak baliagarriak dira ingurumeneko laginak aztertzeko. Ondoren, zenbait adibide aipatuko dira.

\subsection{Euskal kostaldeko monitorizazioa}

Euskal kostalde osoa beren gain hartzen duten 5 puntu aukeratu ziren ikerketa honetarako: Santurtziko portua, Urdaibaiko estuarioa (Gernikako araztegiaren irteera-korrontearen alboan), Ondarroako ibaia, Debako portua eta Pasaiako portua (5. irudia). Lagin-bilketagune bakoitzean, 12-30 lazun (Chelon abrosus) jaso ziren kainaberaz. Arrainen behazuna aztertzeaz gain, ur-laginak jaso ziren arrainek duten biokontzentrazio ahalmena ezagutzeko. Horrez gain, arrainak ar, eme eta intersexetan banatu ziren, generoaren eta arrainetan dauden EDCen arteko lortura bat ezartzeko. SPE teknika klasikoa erabili zen behazun-laginen erauzketaeta garbiketa-urratsetarako. Ur-laginen analisirako, aldiz, PEs bidezko mikroerauzketa egin zen. Aztertutako konposatuen artean, musketa fragantziak, pestizidak, PEsak, BPA, hormona natural zein sintetikoak eta APsak daude. 


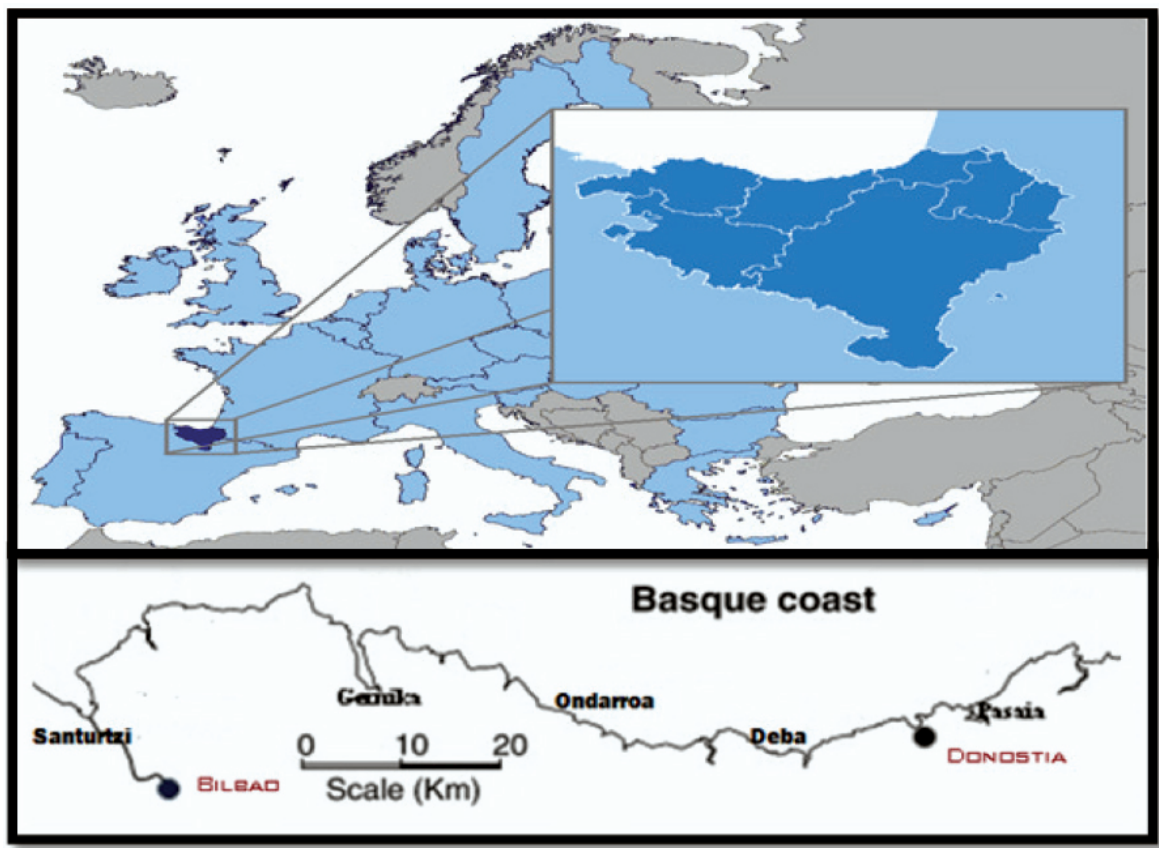

5. irudia. Euskal kostaldean zehar laginak bildu ziren guneak.

Behazun-laginei dagokienez, oro har esan behar da aztertutako konposatu guztiak 3 gunetan gutxienez antzeman zirela (6. irudia). Konposatu gehienak $\mu \mathrm{g} / \mathrm{L}$ kontzentrazio-mailatan aurkitu ziren konposatu gehienentan, zenbait salbuespenekin; DEHP eta NP mix analitoak $\mathrm{mg} / \mathrm{L}$ mailan aurkitu ziren. Aipagarriena Gernikako araztegiko irteeran jasotako arrain baten behazunean neurtutako bis(2-etilhexil ftalatoaren (bis(2-ethylhexyl phthalate, DEHP) kopuruari dagokio, zeinetan $19.226 \mathrm{mg} / \mathrm{L}$ neurtu ziren. Ur-laginei dagokienez, oso konposatu gutxi neurtu ziren, eta konposatu gehien Gernikako araztegiaren irteeran neurtu ziren. Beraz, arrainen behazunaren kontzentrazio-ahalmena baieztatu zen, eta honen balio-tarte logaritmikoa 2,4-5,5 zela ikusi zen.

Azkenik, ur-laginetan eta behazun-laginetan antzemandako kontzentrazioak intersex fenomenoarekin erlazionatzeko saiakera egin zen. Alde batetik, aipatu beharra dago intersex kopururik handiena Gernikan ikusi zela $(n=3)$, uren kutsadura handiena zen tokian, alegia. Aldiz, konposatu gutxien Debako uretan neurtu ziren, baina han bi intersex arrain jaso ziren. Beste alde batetik, Ondarroako ibaian jasotako arrainen behazunean kutsatzaile kopuru handia neurtu zen (6. irudia), baina ez zen inolako intersex arrainik jaso. Hori dela eta, intersexualitatea eta EDC konposatuen arteko 
Oihana Ros, Asier Vallejo, Maitane Olivares, Ailette Prieto,

Nestor Etxebarria

erlazioa guztiz baieztatu ahal izateko, azterketa sakonagoak burutu behar dira. Hori bai, ikerketa honekin, arrainen behazuna biomonitorizaziorako fluidotzat erabil daitekeela berretsi da.

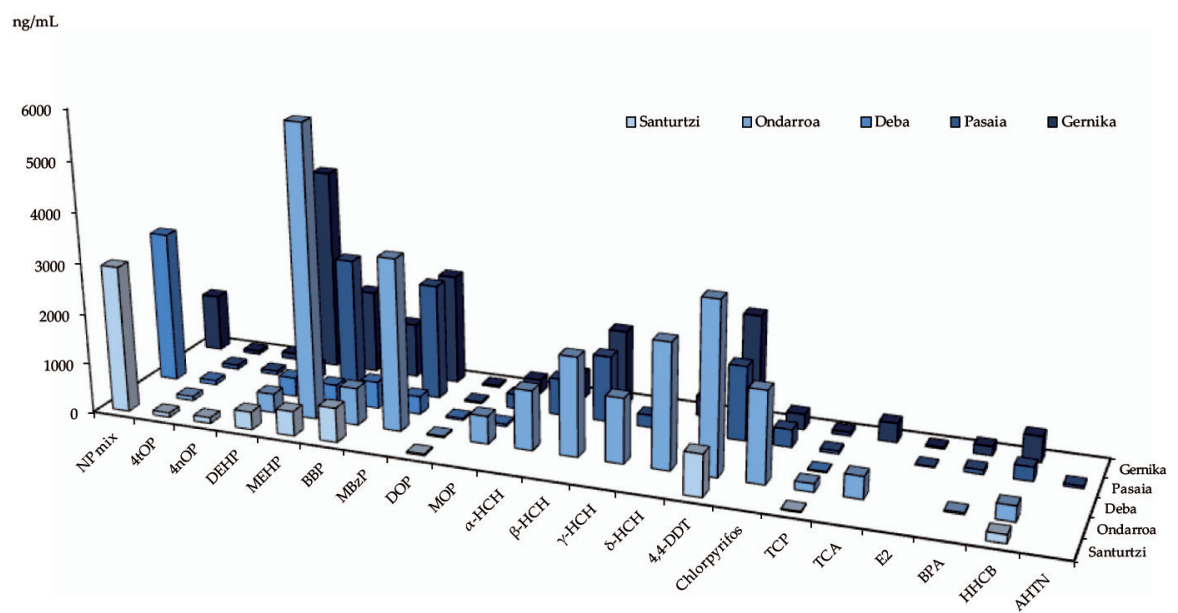

6. irudia. Behazun laginetan dauden kontzentrazioak (ng/mL). Gainerako kontzentrazioak detekzio-muga balioen azpitik daude.

\subsection{EDCen metaketa lazunen organo desberdinetan, Gernikako araztegi ondoan arrantzatutako lazunetan}

Gernikako araztegiaren irteera korrontearen alboan lazunak (Chelon labrosus) jaso ziren haien organoek duten metaketa-gaitasuna, ingurumeneko baldintzetan, aztertzeko asmoz. Horretarako, arrainen gibelean, muskuluan eta burmuinean zeuden EDCak (hormona natural (E2) eta sintetikoak (EE2 eta DES), APsak (4tOP, $4 n \mathrm{OP}$ eta NP nahasketa) eta BPA) aztertu ziren, FUSLE (3.2 atala) eta dSPE (3.3 atala) teknikak erabiliz. Azterturiko konposatuen artean, hormonak izan ziren maila baxuenean zeuden konposatuak. E2 eta 17- $\alpha$-etinil estradiola (17- $\alpha$-ethynil estradiol, EE2) konposatuak ez ziren inoiz atzeman, eta DES arrainen burmuinean baino ez zen aurkitu. Beste hainbat azterketa egin dira hango uretan dauden konposatuen kontzentrazioa neurtzeko, eta aipatu beharra dago hormonak, oro har, detekzio-muga azpitik egon ohi direla edo ng/L maila oso baxuetan. Beraz, konposatu horiek uretan ez egotea izan daiteke hormonak arrainetan ez aurkitu izanaren arrazoietariko bat $[16,76,77]$. Aztertutako gainerako analitoei dagokienez (APsak eta BPA), ng/g mailetan aurkitu ziren, eta kontzentrazio handienean zegoen konposatua NP nahasketa izan zen.

Metaketa-ahalmenari dagokionez, konposatuak gibelean metatu ziren nagusiki, eta muskuluan eta burmuinean antzeko metaketa-maila antzeman 
zen. Lortutako balioak bat datoz bibliografian ikusitakoarekin, lan honen hasieran aipatu den moduan [27].

\subsection{EDCen metaketa arrainen atal desberdinetan, laborategiko kontrolpeko baldintzetan}

Ingurumenean jasotako arrainekin lan egiteak emaitzen hetereogenetasuna ekar dezake arrainen sexua, tamaina eta elikadura-ohiturak kontrolatzea oso zaila edo ia ezinezkoa delako. Arazo horiei aurre egiteko, laborategiko kontrolpeko baldintzetan egindako esperimentuak izan daitezke irtenbide bat.

Lan honetan heldu gabeko lupiak (Dicentrarchus labrax) 4 EDC desberdinen nahasketa (BPA, E2, DES eta 4-tert-oktilfenola (4-tert-octylphenol, 4tOP), $150 \mathrm{ng} / \mathrm{L}$ bakoitzeko) zuen ontzian sartu ziren 10 egunez. Ondoren, beste 12 egunez ontzi garbi batera eraman ziren arazketa-garaiari hasiera emateko. Aipatutako ontziaz gain (kutsatutako ontzia), inolako kutsatzailerik ez zuen ontzi bat ere erabili zen (kontroleko ontzia). Arrainek duten metaketa-ahalmena behazunean, gibelean eta plasman aztertu zen (3. eta 4. atalak). Metaketa-ahalmena aztertzeaz gain, atal desberdinen itxura fisikoak izandako aldaketak ere aztertu ziren.

Itxura fisikoari dagokionez, kutsatutako ontziko arrainetan pisu-galera ikusi zen esperimentuko 10. egunean, baina arazketa garaira helduta, pisuak gora egin zuen. Pentsa liteke, kutsatzaileen presentzia dela eta, arrainen estres-mailak gora egin zuela eta ez zutela gehiegi jan, egunero emandako janaria ontzi hondoan ikusten baitzen. Gibelaren pisuarekin antzeko joera baritu zen, baina kasu honetan arazketa egunak aurrera joan ahala, berriro pisu-galera ikusi zen; beraz, pentsa liteke gibelaren mekanismoa kalteturik zegoela kutsatzaileen ondorioz. Gibelean sumatutako pisu galera kolore-aldaketarekin erlaziona liteke 7. irudian ikusten den moduan. Han ikus daiteke pisu minimoa zen egunetan (esposizioko 7 eta 10. egunetan eta arazketako 7. eta 12. egunetan) kolore ilunenak ikusi zirela.

Gibelean ikusi den moduan, behazunean ere kutsatzaileen presentziaren ondorioz kolore-aldaketak ikusi ziren. 8. irudiaren arabera, kontroleko laginek beti zuten kolore berdea, baina esposizioko egunak aurrera joan ahala, kolorea berdetik zurira igaro zen. Oraingoan, behin arazketa-garaira helduta, bazirudien jatorrizko kolore berdea berreskuratu zela. Oraingoan ere, badirudi kutsatzaileen ondorioz gibelaren metabolismoa kaltetua zegoela.

Gibelaren metabolismoaren kaltetzearen ondorioz gertatutako aldaketak metaketa-azterketarekin zuzenki erlazionatu ziren. 9. Irudian, BPAren adibidea azaltzen da eredu gisa. Esperimentuaren hasieran, BPA behazunean metatu zen lehenbizi, eta kontzentrazio altuenean, espero bezala. Esperimentuak aurrera egin ahala eta behazunaren kolore-aldaketarekin 
Oihana Ros, Asier Vallejo, Maitane Olivares, Ailette Prieto, Nestor Etxebarria
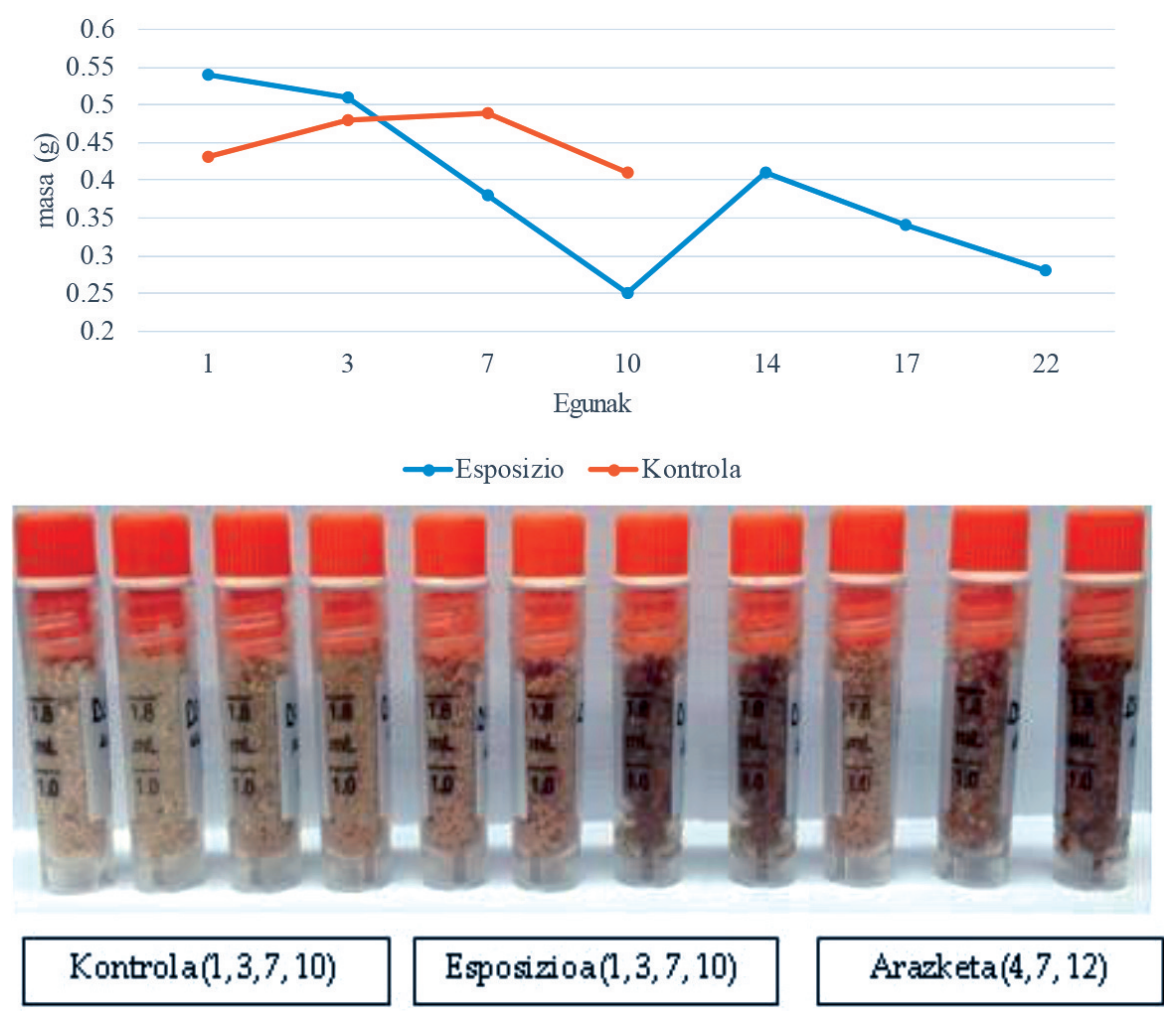

7. irudia. Arrain talde desberdinetan $(n=10)$ jasotako gibelaren masa eta itxura (liofilizatu ostean).

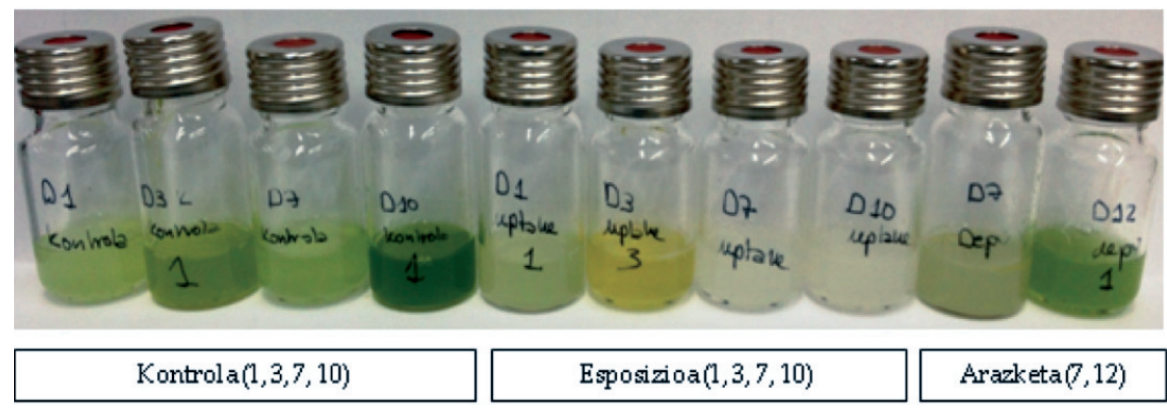

8. irudia. Arrain talde desberdinetan $(n=10)$ jasotako behazunaren kolorea Milli-Q urarekin eta fosfato tampoiarekin diluitu ostean. 
batera (9. irudia), metatze-ahalmena guztiz jaitsi zen. Jaitsiera horren ondorioz, konposatuak gibelean metatzen hasi ziren (9. irudia). Oraingoan ere, gibelaren pisu galerarekin batera, BPA gibeletik plasmara igaro zelako susmoa dago. Gainera, plasman ikusten den igoera hori arazketa-garaian gertatu zen, ontzian inolako kutsatzailerik ez zegoen unean.

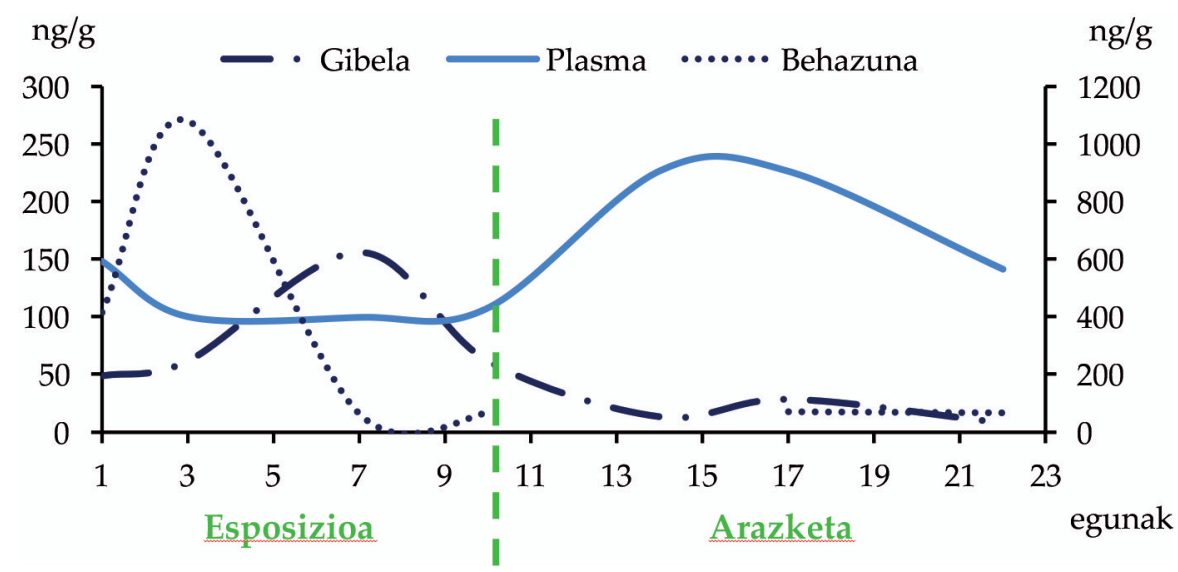

9. irudia. BPA konposatuaren metaketa esposizio- eta arazketa-garaian. Gibela eta plasma-laginak ezkerreko Y ardatzean daude irudikaturik, eta behazun lagina eskumako $Y$ ardatzean. 1-10 egunak esposizio-garaiari dagozkio eta 11-22 egunak arazketa-garaiari.

\section{ONDORIOAK}

Ikerketa lan honen bidez, egiaztatu da kutsatzaileen kontzentrazio baxuak ere nahikoak direla arrainen organismoan kalteak sortzeko . Beraz, kimika analitikoaren ikuspuntutik, oso garrantzitsua da konposatuak maila baxuetan neurtzeko gai diren metodoak garatzea.

\section{BIBLIOGRAFIA}

[1] Central Service. http://www.cas.org/content/chemical-substances (2016. apirila).

[2] Robles-Molina, J., Lara-Ortega, F.J., Gilbert-López, B., García-Reyes, J.F. eta Molina-Díaz, A. 2014. «Multi-residue method for the determination of over 400 priority and emerging pollutants in water and wastewater by solidphase extraction and liquid chromatography-time-of-flight mass spectrometry». J. Chromatogr. A, 1350, 30-43. 
Oihana Ros, Asier Vallejo, Maitane Olivares, Ailette Prieto, Nestor Etxebarria

[3] Primel, E.G., Caldas, S.S. eta Escarrone, A.L.V. 2012. «Multi-residue analytical methods for the determination of pesticides and PPCPs in water by LC-MS/MS: a review». Cent. Eur. J. Chem,. 10 (3), 876-899.

[4] European commission. Introduction to the new EU Water Frame Directive, http://ec.europa.eu/environment/water/water-framework/info/intro_en.htm (2016. maiatza).

[5] WFD Directive 2008/105/EC of the European Parliament and the Council on environmental quality standards in the field of water policy amending Directive 2000/60/EC, http://ec.europa.eu/environment/water/water-framework/ priority_substances.htm (2016. maiatza).

[6] WFD European Directive 2000/60/EC establishing a framework for community action in the field of water policy http://eur-lex.europa.eu/resource. html?uri=cellar:5c835afb-2ec6-4577-bdf8-756d3d694eeb.0004.02/ DOC_1\&format=PDF (2016 maiatza).

[7] Directive, W. F. European Directive 2013/39/EC amending directives $2000 / 60 / \mathrm{EC}$ and 2008/105/EC as regards priority substances in the field of water policy http://eur-lex.europa.eu/legal-content/EN/TXT/PDF/?uri=CEL EX:32013L0039\&from=EN. (2016. maiatza),

[8] US Environmental Protection Agency, P. P. US Environmental Protection Agency, Priority Pollutants. https://www.epa.gov/sites/production/ files/2015-09/documents/priority-pollutant-list-epa.pdf

[9] European Union. Commission implementing decision (EU) 2015/495 of 20 March 2015. http://eur-lex.europa.eu/legal-content/EN/TXT/PDF/?uri=CEL EX:32015D0495\&from=EN (2016. maiatza).

[10] EPA US Environmental Protection Agency, Contaminants of emerging concern https://www.epa.gov/ccl/contaminant-candidate-list-3-ccl-3\#chemicallist (2016. maiatza).

[11] NORMAN List of emerging substances http://www.normandata. $\mathrm{eu} / \mathrm{q}=$ node/19 (2016. maiatza).

[12] Bergman, Å., Heindel, J.J.,Jobling, S., Kidd, K.A. eta Zoeller, R.T. 2012. «State of the science of endocrine disrupting chemicals - 2012. An assessment of the state of the science of endocrine disruptors prepared by a group of experts for the United Nations Environment Programme (UNEP) and WHO» World Health Organization.

[13] JAKIMSKA, A., HUERTA, B., BARGAŃSKA, Ż., KOT-WASIK, A., RODRÍGUEZ-MOZAZ, S. eta BARCELÓ, D. 2013. «Development of a liquid chromatography-tandem mass spectrometry procedure for determination of endocrine disrupting compounds in fish from Mediterranean rivers». $J$. Chromatogr. A, 1306, 44-58.

[14] ISHIBASHI, H., HIRANO, M., MATSUMURA, N., WATANABE, N., TAKAO, Y. eta ARIZONO, K. 2006. «Reproductive effects and bioconcentration of 4-nonylphenol in medaka fish (Oryzias latipes)». Chemosphere, 65, 1019-1026. 
15] TANCIONI, L., CAPRIOLI, R., AL-KHAFAJI, A., MANCINI, L., BOGLIONE, C., CICCOTTI, E. eta CATAUDELLA, S. 2015. «Gonadal Disorder in the Thinlip Grey Mullet (Liza ramada, Risso 1827) as a Biomarker of Environmental Stress in Surface Waters». Int. J. Environ. Res. Public Heal., $12,1817$.

[16] BIZARRO, C., ROS, O., VALLEJO, A., PRIETO, A., ETXEBARRIA, N., CAJARAVILLE, M. P. eta ORTIZ-ZARRAGOITIA, M. 2014. «Intersex condition and molecular markers of endocrine disruption in relation with burdens of emerging pollutants in thicklip grey mullets (Chelon labrosus) from Basque estuaries (South-East Bay of Biscay)». Mar. Environ. Res., 96, 19-28.

[17] TYLER, C. R. eta JOBLING, S. 2008. «Roach, Sex, and Gender-Bending Chemicals: The Feminization of Wild Fish in English Rivers». BioScience, 58, 1051-1059.

[18] HARRIS, C.A., HAMILTON, P.B., RUNNALLS, T.J., VINCIOTTI, V., HENSHAW, A., HODGSON, D., COE, T. S., JOBLING, S., TYLER, C.R. eta SUMPTER, J.P. 2011. «The Consequences of Feminization in Breeding Groups of Wild Fish». Environ. Health Perspec,. 119, 306-311.

[19] MATTHIESSEN, P. 2003. «Endocrine disruption in marine fish. Pure Appl. Chem, 75, 2249.

[20] LIU, J., WANG, R., HUANG, B., LIN, C., WANG, Y. eta PAN, X. 2011. «Distribution and bioaccumulation of steroidal and phenolic endocrine disrupting chemicals in wild fish species from Dianchi Lake, China». Environ. Pollut., 159, 2815-2822.

[21] HAMPL, R., KUBÁTOVÁ, J. eta STÁRKA, L. 2014. «Steroids and endocrine disruptors-History, recent state of art and open questions». J. Steroid Biochem. Mol. Biol., 155 Part B, 217-223.

[22] SÁNCHEZ-AVILA, J., FERNANDEZ-SANJUAN, M., VICENTE, J. eta LACORTE, S. 2011. «Development of a multi-residue method for the determination of organic micropollutants in water, sediment and mussels using gas chromatography-tandem mass spectrometry». J. Chromatogr. A, 1218, 6799-6811.

[23] YANG, L., LUAN, T. eta LAN, C. 2006. «Solid-phase microextraction with on-fiber silylation for simultaneous determinations of endocrine disrupting chemicals and steroid hormones by gas chromatography-«mass spectrometry». J. Chromatogr. A, 1104, 23-32.

[24] BIZKARGUENAGA, E., ROS, O., IPARRAGUIRRE, A., NAVARRO, P., VALLEJO, A., USOBIAGA, A. eta ZULOAGA, O. 2012 «Solid-phase extraction combined with large volume injection-programmable temperature vaporization-gas chromatography-mass spectrometry for the multiresidue determination of priority and emerging organic pollutants in wastewater». J. Chromatogr. A, 1247, 104-117.

[25] BLANCO-ZUBIAGUIRRE, L., DELGADO, A., ROS, O., POSADAURETA, O., VALLEJO, A., PRIETO, A., OLIVARES, M. eta ETXEBARRIA, N. 2014. «Assessment of commercially available polymeric materials 
Oihana Ros, Asier Vallejo, Maitane Olivares, Ailette Prieto, Nestor Etxebarria

for sorptive microextraction of priority and emerging nonpolar organic pollutants in environmental water samples». Environ. Sci. Pollut. Res., 21, 11867-11883.

[26] BASTOS, P.M. eta HAGLUND, P. 2012. «The use of comprehensive twodimensional gas chromatography and structure-«activity modeling for screening and preliminary risk assessment of organic contaminants in soil, sediment, and surface water». J. Soil. Sediment., 12, 1079-1088.

[27] FERREIRA-LEACH, A.M.R. eta HILL, E. M. 2001. «Bioconcentration and distribution of 4-tert-octylphenol residues in tissues of the rainbow trout (Oncorhynchus mykiss)». Mar. Environ. Res., 51, 75-89.

[28] MARTÍNEZ-GÓMEZ, C., LAMOREE, M., HAMERS, T., VAN VELZEN, M., KAMSTRA, J.H., FERNÁNDEZ, B., BENEDICTO, J., LEÓN, V.M. eta VETHAAK, A. D. 2013. «Integrated chemical and biological analysis to explain estrogenic potency in bile extracts of red mullet (Mullus barbatus) ». Aquat. Toxicol, 134-135, 1-10.

[29] YU, Y. eta WU, L. 2015. «Determination and occurrence of endocrine disrupting compounds, pharmaceuticals and personal care products in fish (Morone saxatilis) ». Front. Environ. Sci. Eng., 9, 475-481.

[30] BUDZINSKI, H., DEVIER, M.H., LABADIE, P. eta TOGOLA, A. 2006. «Analysis of hormonal steroids in fish plasma and bile by coupling solidphase extraction to GC/MS». Anal. Bioanal. Chem., 386, 1429-1439.

[31] SAMANDAR, E., SILVA, M.J., REIDY, J. A., NEEDHAM, L.L. eta CALAFAT, A.M. 2009. «Temporal stability of eight phthalate metabolites and their glucuronide conjugates in human urine». Environ. Res., 109, 641-646.

[32] YANG, J., LI, H., RAN, Y. eta CHAN, K. 2014. «Distribution and bioconcentration of endocrine disrupting chemicals in surface water and fish bile of the Pearl River Delta, South China». Chemosphere, 107, 439-446.

[33] VALLEJO, A., USOBIAGA, A., ORTIZ-ZARRAGOITIA, M., CAJARAVILLE, M.P., FERNÁNDEZ, L.A. eta ZULOAGA, O. 2010. «Focused ultrasound-assisted acceleration of enzymatic hydrolysis of alkylphenols and $17 \beta$-oestradiol glucuronide in fish bile». Anal. Bioanal. Chem., 398, 23072314.

[34] FENLON, K.A., JOHNSON, A.C., TYLER, C.R. eta HILL, E.M. 2010. «Gas-liquid chromatography-tandem mass spectrometry methodology for the quantitation of estrogenic contaminants in bile of fish exposed to wastewater treatment works effluents and from wild populations». J. Chromatogr. A, 1217, 112-118.

[35] PEDERSEN, R.T. eta HILL, E. M. 2002. «Tissue Distribution and Depuration of 4-tert-Octylphenol Residues in the Cyprinid Fish, Scardinius erythrophthalmus». Environ. Sci. Technol., 36, 3275-3283.

[36] LEGLER, J., JONAS, A., LAHR, J., VETHAAK, A.D.. BROUWER, A. eta MURK, A.J. 2002. «Biological measurement of estrogenic activity in urine and bile conjugates with the in vitro ER-CALUX reporter gene assay». Environ. Toxicol. Chem., 21, 473-479. 
[37] LiNDHOLST, C., PEDERSEN, S.N. eta BJERREGAARD, P. 2001. «Uptake, metabolism and excretion of bisphenol $\mathrm{A}$ in the rainbow trout (Oncorhynchus mykiss) ». Aquat. Toxicol, 55, 75-84.

[38] LIU, Z.-H., LU, G.-N., YIN, H., DANG, Z., LITTIER, H. eta LIU, Y. 2015. «Sample-preparation methods for direct and indirect analysis of natural estrogens». TrAC Trend. Anal. Chem., 64, 149-164.

[39] MORTAZAVI, S., BAKHTIARI, A.R., SARI, A.E., BAHRAMIFAR, N. eta RAHBARIZADEH, F. 2013. «Occurrence of Endocrine Disruption Chemicals (Bisphenol A, 4-Nonylphenol, and Octylphenol) in Muscle and Liver of, Cyprinus Carpino Common, from Anzali Wetland, Iran». Bull. Environ. Contam. Toxicol, . 90, 578-584.

[40] SERRANO, R., LÓPEZ, F.J., ROIG-NAVARRO, A. eta HERNÁNDEZ, F. 1997. «Automated sample clean-up and fractionation of chlorpyrifos, chlorpyrifos-methyl and metabolites in mussels using normal-phase liquid chromatography». J. Chromatogr. A, 778, 151-160.

[41] DA SILVA, D.A.M., BUZITIS, J., REICHERT, W.L., WEST, J.E., O'NEILL, S.M., JOHNSON, L.L., COLLIER, T.K. eta YLITALO, G.M. 2013. «Endocrine disrupting chemicals in fish bile: A rapid method of analysis using English sole (Parophrys vetulus) from Puget Sound, WA, USA». Chemosphere, 92, 1550-1556.

[42] VALLECILlOS, L., POCURULL, E. eta BORRULL, F. 2015. «Influence of pre-treatment process on matrix effect for the determination of musk fragrances in fish and mussel». Talanta, 134, 690-698.

[43] LABADIE, P. eta BUDZINSKI, H. 2006. «Alteration of Steroid Hormone Balance in Juvenile Turbot (Psetta maxima) Exposed to Nonylphenol, Bisphenol A, Tetrabromodiphenyl Ether 47, Diallylphthalate, Oil, and Oil Spiked with Alkylphenols». Arc. Environ. Contam. Toxicol., 50, 552-561.

[44] PLASSMANN, M.M., SCHMIDT, M., BRACK, W. eta KRAUSS, M. 2015. «Detecting a wide range of environmental contaminants in human blood samples-combining QuEChERS with LC-MS and GC-MS methods». Anal. Bioanal. Chem. 407, 7047-7054.

[45] PRIETO, A., RODIL, R., QUINTANA, J.B., RODRÍGUEZ, I., CELA, R. eta MÖDER, M. 2012. «Evaluation of low-cost disposable polymeric materials for sorptive extraction of organic pollutants in water samples». Anal. Chim. Acta, 716, 119-127.

[46] LI, S., ZHU, F., JIANG, R. eta OUYANG, G. 2016. «Preparation and evaluation of amino modified graphene solid-phase microextraction fiber and its application to the determination of synthetic musks in water samples». J. Chromatogr. A, 1429, 1-7.

[47] ARTHUR, C.L. eta PAWLISZYN, J. 1990. «Solid phase microextraction with thermal desorption using fused silica optical fibers». Anal. Chem., 62, 2145-2148.

[48] ARESTA, A., BIANCHI, D., CALVANO, C.D. eta ZAMBONIN, CG. 2010. «Solid phase microextraction-Liquid chromatography (SPME-LC) de- 
Oihana Ros, Asier Vallejo, Maitane Olivares, Ailette Prieto, Nestor Etxebarria

termination of chloramphenicol in urine and environmental water samples». J. Pharmaceut. Biomed., 53, 440-444.

[49] TOGUNDE, O.P., OAKES, K.D., SERVOS, M.R. eta PAWLISZYN, J. 2012. «Determination of Pharmaceutical Residues in Fish Bile by SolidPhase Microextraction Couple with Liquid Chromatography-Tandem Mass Spectrometry (LC/MS/MS) ». Environ. Sci. Technol., 46, 5302-5309.

[50] ARANDA-RODRIGUEZ, R., CABECINHA, A., HARVIE, J., JIN, Z., MARCHAND, A., TARDIF, R., NONG, A. eta HADDAD, S. 2015. «A method for quantification of volatile organic compounds in blood by SPMEGC-MS/MS with broader application: From non-occupational exposure population to exposure studies». J. Chromatogr. B, 992, 76-85.

[51] VILLAVERDE-DE-SÁA, E., RACAMONDE, I., QUINTANA, J.B., RODIL, R. eta CELA, R. 2012. «Ion-pair sorptive extraction of perfluorinated compounds from water with low-cost polymeric materials: Polyethersulfone vs polydimethylsiloxane». Anal. Chim. Acta, 740, 50-57.

[52] ADEOGUN, A.O., IBOR, O.R., OMOGBEMI, E.D., CHUKWUKA, A.V., ADEGBOLA, R.A., ADEWUYI, G.A. eta ARUKWE, A. 2015. «Environmental occurrence and biota concentration of phthalate esters in Epe and Lagos Lagoons, Nigeria». Mar. Environ.Res., 108, 24-32.

[53] HELALEH, M.I H., AL-RASHDAN, A. eta IBTISAM, A. 2012. «Simultaneous analysis of organochlorinated pesticides (OCPs) and polychlorinated biphenyls (PCBs) from marine samples using automated pressurized liquid extraction (PLE) and Power Prep ${ }^{\mathrm{TM}}$ clean-up». Talanta, 94, 44-49.

[54] ANTUNES, P., VIANA, P., VINHAS, T., CAPELO, J.L., RIVERA, J. eta GASPAR, E.M.S.M. 2008. «Optimization of pressurized liquid extraction (PLE) of dioxin-furans and dioxin-like PCBs from environmental samples». Talanta, 75, 916-925.

[55] NAVARRO, P., BUSTAMANTE, J., VALlEJO, A., PRIETO, A., USOBIAGA, A., ARRASATE, S., ANAKABE, E., PUY-AZURMENDI, E. eta ZULOAGA, O. 2010. «Determination of alkylphenols and $17 \beta$-estradiol in fish homogenate. Extraction and clean-up strategies». J. Chromatogr. A, 1217, 5890-5895.

[56] NAVARRO, P., ETXEBARRIA, N. eta ARANA, G. 2009. «Development of a focused ultrasonic-assisted extraction of polycyclic aromatic hydrocarbons in marine sediment and mussel samples». Anal.Chim. Acta, 648, 178-182.

[57] SANZ-LANDALUZE, J., BARTOLOME, L., ZULOAGA, O., GONZÁLEZ, L., DIETZ, C. eta CÁMARA, C. 2006. «Accelerated extraction for determination of polycyclic aromatic hydrocarbons in marine biota». Anal. Bioanal. Chemistry, 384, 1331-1340.

[58] ZABALETA, I., BIZKARGUENAGA, E., PRIETO, A., ORTIZ-ZARRAGOITIA, M., FERNÁNDEZ, L. A. eta ZULOAGA, O. 2015. «Simultaneous determination of perfluorinated compounds and their potential precursors in mussel tissue and fish muscle tissue and liver samples by liquid chromatography-electrospray-tandem mass spectrometry». J. Chromatogr. A, 1387, 13-23. 
[59] OMAR, J. eta VALLEJO, A. 2014.«Ingurumen-kutsaduraren analisia». Udako Euskal Unibertsitatea, Euskal Herria.

[60] MiJANGOS, L., BIZKARGUENAGA, E., PRIETO, A., FERNÁNDEZ, L. A. eta ZULOAGA, O. 2015. «Simultaneous determination of a variety of endocrine disrupting compounds in carrot, lettuce and amended soil by means of focused ultrasonic solid-liquid extraction and dispersive solid-phase extraction as simplified clean-up strategy». J. Chromatogr. A, 1389, 8-18.

[61] POUECH, C., TOURNIER, M., QUIGNOT, N., KISS, A., WIEST, L., LAFAY, F., FLAMENT-WATON, M.M., LEMAZURIER, E. eta CRENOLIVÉ, C. 2012. «Multi-residue analysis of free and conjugated hormones and endocrine disruptors in rat testis by QuEChERS-based extraction and LC-MS/MS». Anal. Bioanal. Chem., 402, 2777-2788.

[62] MATĚJÍČEK, D. eta KUBÁŇ, V. 2008. «Enhancing sensitivity of liquid chromatographic/ion-trap tandem mass spectrometric determination of estrogens by on-line pre-column derivatization». J. Chromatogr. A, 1192, 248-253.

[63] POJANA, G., GOMIERO, A., JONKERS, N. eta MARCOMINI, A. 2007. «Natural and synthetic endocrine disrupting compounds (EDCs) in water, sediment and biota of a coastal lagoon». Environ. Int., 33, 929-936.

[64] WANG, B., DONG, F., CHEN, S., CHEN, M., BAI, Y., TAN, J., LI, F. eta WANG, Q. 2016. «Phenolic endocrine disrupting chemicals in an urban receiving river (Panlong river) of Yunnan-Guizhou plateau: Occurrence, bioaccumulation and sources». Ecotoxicol. Environ. Saf., 128, 133-142.

[65] NORLI, H. R., CHRISTIANSEN, A. eta DERIBE, E. 2011. «Application of QuEChERS method for extraction of selected persistent organic pollutants in fish tissue and analysis by gas chromatography mass spectrometry». J. Chromatogr. A, 1218, 7234-7241.

[66] ANASTASSIADES, M., LEHOTAY, S.J., TAJNBAHER, D. eta SCHENCK, F. J. 2003. «Fast and Easy Multiresidue Method Employing Acetonitrile Extraction/Partitioning and «Dispersive Solid-Phase Extraction» for the Determination of Pesticide Residues in Produce». J. AOAC Int., 86, 412-431.

[67] USUI, K., HAYASHIZAKI, Y., MINAGAWA, T., HASHIYADA, M., NAKANO, A. eta FUNAYAMA, M. 2016. «Rapid determination of disulfoton and its oxidative metabolites in human whole blood and urine using QuEChERS extraction and liquid chromatography-tandem mass spectrometry». Legal Med., 14, 309-316.

[68] MU, P., XU, N., CHAI, T., JIA, Q., YIN, Z., YANG, S., QIAN, Y. eta QIU, J. 2016. «Simultaneous determination of 14 antiviral drugs and relevant metabolites in chicken muscle by UPLC-MS/MS after QuEChERS preparation». J. Chromatogr. B, 1023-1024, 17-23.

[69] LISCIO, C., MAGI, E., DI CARRO, M., SUTER, M.J.F. eta VERMEIRSSEN, E.L.M. 2009. «Combining passive samplers and biomonitors to evaluate endocrine disrupting compounds in a wastewater treatment plant by LC/ MS/MS and bioassay analyses». Environ. Pollut., 157, 2716-2721. 
Oihana Ros, Asier Vallejo, Maitane Olivares, Ailette Prieto, Nestor Etxebarria

[70] LU, Y. eta WANG, Z. 2003. «Accumulation of organochlorinated pesticides by triolein-containing semipermeable membrane device (triolein-SPMD) and rainbow trout». Water Res. 2003, 37, 2419-2425.

[71] MACKAY, D. eta FRASER, A. 2000. «Bioaccumulation of persistent organic chemicals: mechanisms and models». Environ. Pollut., 110, 375-391.

[72] GOVERMENT OF CANADA, 1995, Toxic Substances Management Policy - Persistence and Bioaccumulation Regulations SOR/2000-107 http://lawslois.justice.gc.ca/eng/regulations/SOR-2000-107/page-1.html\#h-1.

[73] LEE, C.C., JIANG, L.Y., KUO, Y.L., CHEN, C.Y., HSIEH, C.Y., HUNG, C.F. eta TIEN, C.J. 2015. «Characteristics of nonylphenol and bisphenol A accumulation by fish and implications for ecological and human health». Sci. Total Environ., 502, 417-425.

[74] INOUE, Y., HASHIZUME, N., YOSHIDA, T., MURAKAMI, H., SUZUKI, Y., KOGA, Y., TAKESHIGE, R., KIKUSHIMA, E., YAKATA, N. eta OTSUKA, M. 2012. «Comparison of Bioconcentration and Biomagnification Factors for Poorly Water-Soluble Chemicals Using Common Carp (Cyprinus carpio L.) ». Arch. Environ. Contam. Toxicol., 63, 241-248.

[75] GARG, R. eta SMITH, C. J. 2014. «Predicting the bioconcentration factor of highly hydrophobic organic chemicals». Food Chem. Toxicol., 69, 252-259.

[76] ROS, O., IZAGUIRRE, J. K., OLIVARES, M., BIZARRO, C., ORTIZZARRAGOITIA, M., CAJARAVILLE, M. P., ETXEBARRIA, N., PRIETO, A. eta VALLEJO, A. 2015. «Determination of endocrine disrupting compounds and their metabolites in fish bile». Sci. Total Environ., 536, 261-267.

[77] ROS, O., VALLEJO, A., BLANCO-ZUBIAGUIRRE, L., OLIVARES, M., DELGADO, A., ETXEBARRIA, N. eta PRIETO, A. 2015. «Microextraction with polyethersulfone for bisphenol-A, alkylphenols and hormones determination in water samples by means of gas chromatography-mass spectrometry and liquid chromatography-tandem mass spectrometry analysis». Talanta, 134, 247-255. 